九州大学学術情報リポジトリ

Kyushu University Institutional Repository

\title{
The Family Curculionidae of Japan : VI. Tribe Mechistocerini Part 1 (Insecta, Coleoptera)
}

Morimoto, Katsura

Entomological Laboratory, Faculty of Agriculture, Kyushu University

https://doi.org/10.5109/23854

出版情報：九州大学大学院農学研究院紀要. 31 (4)，pp.321-343，1987-03-31. Kyushu University バージョン：

権利関係 : 
J. Fac. Agr., Kyushu Univ., 31 (4), 321-343 (1987)

\title{
The Family Curculionidae of Japan \\ VI. Tribe M echistocerini Part 1 \\ (Insecta, Coleoptera) *
}

\author{
Katsura M orimoto \\ Entomological Laboratory, Faculty of Agriculture, \\ Kyushu University, Fukuoka 812, Japan \\ (Received December 8, 1986)
}

\begin{abstract}
A revision of the cryptorhynchine tribe Mechistocerini of Japan is presented including 3 genera and 17 species. In part I genus Mechistocerns is treated. New species are :Mechisto cerus okumai sp. nov., M.ochraceus sp. nov., M. yakuskimanus sp. nov., M. iriei sp. nov., $M$. yaeyamensis sp. nov., and M. similis sp. nov.
\end{abstract}

In continuation of my studies on the weevil fauna of Japan, I reviewed the tribe Mechistocerini in the present paper.

This tribe was established by Morimoto (1978) for receiving M echistocems and its allied genera previously included in the Sophrorhinini, and keys to genera were given by Heller (1937) and Morimoto (1978). This is one of the most difficult tribes for separating the genera owing to their inter-and intraspecific variations.

The materials treated in this study contain 17 species from Japan, together with about 70 species for comparison from the tropical and subtropical countries in eastern Asia including Papua New Guinea. I have also examined the Oriental species in the British Museum (Natural History), London, described or identified by Marshall and Pascoe, and the types in the Schoenherr collection in the Naturhistoriska Riksmuseum, Stockholm.

I heartly thanks those who sent me specimens for the present study : Dr. K. Baba, Prof. M. T. Chûjô, Mr. K. Emoto, Mr. H. Ichihashi, Mr. H. Irie, Prof. S. Kimoto, Prof. K. Kojima, Mr. H. Makihara, Mr. T. Matoba, Mr. T. Mikage, Dr. S. Miyakawa, Mr. Y. Miyake, Mr. Y. Miyatake, Prof. Y. Murakami, Mr. J. Nagao, Mr. T. Ogasawara, Prof. H. Sasaji, Dr. T. Senoh, Prof. T. Shirôzu, Dr. S. Uëno, Mr. K. Yoshihara and many other friends. My thanks are also due to Prof. Y. Hirashima, of Kyushu University, for his kind guidance in the course of the present study.

\section{Tribe M echistocerini}

Mecistocerini Morimoto, 1978, Esakia, (11) : 122.

Sous-Tribu Sophrorhinides Lacordaire, 1866, Gen. Col., VII : 81 (partim).

Sect. Sophrorhinides Champion, 1905, Biol. Centr. -Amer., Col., IV (4) :459 (partim).

* Contribution from the Entomological Laboratory, Faculty of Agriculture, Kyushu University, Fukuoka (Ser. 3, No. 231). 
Tribu Sophrorhinini Hustache, 1924, Bull. Acad. Malg., VII : 9 (partim).

"Sophrorrhininae" Gardner, 1934, Ind. For. Rec., XX : 17 (larvae).

Tribus Sophrorrhini Hustache, 1936, Col. Cat., 151, Curculionidae : Cryptorrhynchinae : 71 (partim).

Mecistocerus verwandten Gattungen, Heller, 1937, Arb. morph. taxon. Ent. Dahlem, 4 : 269.

Tribus Sophrorhinini Voss, 1958, Decheniana, Beihefte $5: 50$.

Adults : Pectoral canal extending onto metasternum. Postcoxal part of prosternum and antecoxal part of mesosternum with lamellae limiting the pectoral canal laterally. Mesocoxae open internally and touching rostrum in repose.

Larvae : Posterior end of body with a large retractible portion with six slender lobes and bearing anus near the base (after Gardner, 1934).

Key to genera

1 (2) Femora clavate, anterior margin of the base continuously naked from the dorsal surface ; first suture between first and second ventrites deep on each side and weak or obsolecent at the middle, especially in male.

Mechistocerus Fauvel

2 (1) Femora scarcely clavate or linear, not naked at base or the naked area limited to the anterior edge seen ventrally; first suture between first and second ventrites distinct throughout its length in both sexes.

3 (4) Antennae inserted before the middle of rostrum ; fore legs much longer than hind ; fore tibiae clothed with long hairs along inner margin in male ; femora of the same width throughout, without naked area at base seen ventrally, with concolorous scales ; prothorax and underside with distant shallow punctures, each puncture covered by a round flat scale. …............ Parendymia Kirsch

4 (3) Antennae inserted at or a little behind the middle of rostrum; fore legs not longer than hind; femora often very weakly dilated from the base to the toothed portion, often with narrow naked margin at the base seen ventrally, with darker patches or rings at the swollen part and apex ; fore tibiae not fringed with long hairs; prothorax and underside with deep large dense punctures, each puncture with a longer suberectscale. $\cdots$ Rhadinomerus Faust

\section{Mechistocerus Fauvel}

M echistocerus Fauvel, 1862, Bull. Soc. Linn. Normandie, VII : 159 (type-species Coelostermus impressus Montrouz, 1860). -Lacordaire, 1866, Gen. Col., VII : 83. -Faust, 1892, Stett. ent. Zeit., LIII : 46 (= Berosiris Pascoe). -Faust, 1892, Stett. ent. Zeit., LIII : 214, 215 (comp. w. Sophronopterus \& Rhadinomerus). -Faust, 1894, Ann. Mus. civ. Stor. nat. Genova, (2) XIV (XXXIV): 265. -Faust. 1898, Stett. ent. Zeit., LIX : 145 (comp. w. Isotocerus).-Heller, 1904, Ent. Tidskr., 25 : 186 (key to Afr. spp.).-Hustache, 1924, Bull. Acad. Malg., N. S., VII : 402 (key to Malag. spp.). -Lea, 1928, Rec. S. Austr. Mus., IV : 49. -Hustache, 1936, Col. Cat., 151, Curculionidae : Cryptorrhynchinae : 79. -Marshall, 1939, Ann. Mag. nat. Hist., (11) 3 : 583 (= Monaulax Roelofs).

M ecistocerus Gemminger et Harold, 1871, Cat. Col., VIII : 2552 (unjustified emendation). -Pascoe, 1875, Ann. Mag. nat. Hist., (4) XVI : 63. -Lea, 1907, Proc. Linn. Soc. N. S. Wales, XXX11 (2) : 403 (key to Austr. spp.). -Heller, 1921, Philipp. J. Sci., $19: 581$ (=Isotocenus, key to Philipp. spp.). -Marshall, 
1921, Bull. ent. Res., XII : 170 (distinguishing characters from Rhadinomerus).-Heller, 1937, Arb. morph. tax. Ent. Dahlem, 4: 269 (key to allied genera). -Marshall, 1958, Rev. 2001. Bot. afr., LVIII: 260 (key to Belgian Congo spp.). -Morimoto, 1962, J. Fac. Agr., Kyushu Univ., 12: 61 (key). -Morimoto, 1978, Esakia, (11): 126 (key to allied genera). -Chao \& Chen, 1980, Econ. Ent. China, 20, Curc. (1) : 145 (key to Chinese spp.). -Morimoto, 1984, Coleopt. Jap. in col., IV : 331.

Berosinis Pascoe, 1876, J. Linn. Soc. Lond., XII : 43 (type-species : Cyamobolus marci Boheman, 1844, designated by Faust, 1892).

Isotocerus Faust, 1898, Stett. ent. Zeit., LIX : 145 (type species : Isotocerus petax Faust, 1898, designated by Heller, 1921). -Heller, 1921, Philipp. J. Sci., XIX : 582 (== Mecistocerus Fauvel). -Heller, 1937, Arb. morph. tax. ent. Dahlem, 4 : 269 (independent genus, key). -Morimoto, 1978, Esakia, (11) : 126.

Monaulax Roelofs, 1875, Ann. Soc. ent. Belg., XVIII : 162 (type-species : Monaulax nugicollis Roelofs, 1875, by monotypy). -Morimoto, 1962, J. Fac. Agr., Kyushu Univ., 12 : 61 (key).

Faust established Isotocerus on the following characters : Pectoral canal reaches the middle of middle coxae. Antennal scrobes are oblique, their dorsal carinae reach near the middle of eyes. Femora are hardly naked at the base ; hind femora do not reach the apex of elytra. Tibiae are less depressed and curved at the base. Antennae are interted before the middle of rostrum in both sexes.

So far as I have examined on the Oriental species before me, three species from Papua New Guinea agree well with these characters and have robuster rostrum and legs, while in the other species the antennae are inserted at or near the middle, the dorsal carinae of the antennal scrobes are directing to the top of eyes, the pectoral canal is reaching posteriorly beyond the middle or to the hind margin of the middle coxae, and the anterior margin of the femora are continuously naked from the dorsal surface at the base. These are species of the genus Mechistocerus sensu Faust. Heller (1921) once synonymized Isotocerus with Mechistocerus and Hustache (1936) followed him in Coleopterorum Catalogus, but Heller (1938) treated Isotocerus as an independent genus without giving comment.

The synonymic treatment of Berosiris with Mechistocerus is agreeable for me. Monaulax is somewhat similar to Isotocerus in having the shorter rostrum, its pectoral canal is hardly beyond the middle of middle coxae and the hind femora are not reaching the apex of elytra. This is characteristic in the base of rostrum, which is not constricted at sides, as broad as the forehead between eyes, and scarcely depressed transversely.

As mentioned above, Mechistocerus (=Berosiris), Isotocerus and Monaulax are seemed to be constitute a natural group respectively.

The relation between Mechistocerus and Rhudinomerus must be reviewed here.

Rhudinomerus was established for receiving Mechistocerus mastersi Pascoe and its relatives on the characters of its linear femora, free second ventrite from the first, broader intercoxal process of abdomen, and not naked femora at the base. Heller (1904) treated Rhudinomerus as a subgenus of Mechistocerus because of the differences in the structure of venter used by Faust are quite unreliable. Marshall (1921) gave new diagnostic characters to Rhadinomerus that it entirely lacks the apical stridulatory apparatus in both sexes and the eighth abdominal tergite is distinctly transverse in the female, while in Mechistocerus the stridulatory apparatus are present in both sexes and the eighth abdominal tergite is as long as or longer than broad in the female. So far as I have examined, a pair of longitudinal or curved rows of stout spines, which are the 
scrapers of the stridulatory apparatus, are always present on seventh tergite in the Japanese species of Mechistocerus and also present in some species of Rhadinomerus, and the relative breadth of the eighth tergite in the female is unreliable in Japanese species for separating these genera.

Mechistocerus is defined in this paper as follows : Femora distinctly clavate, continuously naked at anterior margin of the base from the dorsal surface in most species, hind femora reaching at least the fifth ventrite. Stridulation apparatus is always present in both sexes. Male aedeagus with or without scletie at gonopore, if present, the shape is not two short juxtaposed hairpin-shaped.

\section{Key to species}

1(4) Body subcylindrical, elytra twice as long as broad, pronotum without median carina, hind femora not reaching the apex of elytra, hind tibiae curved at basal third, rostrum not constricted laterally and hardly depressed transversely at the base, first segment of funicle longer than second..

2 ( 3 ) Femora with broad black apex and a black patch at the swollen part; rostrum distinctly carinate on basal third in female ; tibiae weakly bisinuate internally ; paler scales reddish brown. ….................... okumai sp. nov.

3( 2 ) Femora with concolorous greyish scales, at most with narrow dark area at apex ; rostrum with carinae obsolete in female ; tibiae distinctly bisinuate internally ; paler scales greyish......................... rugicollis (Roelofs)

$4(1)$ Body robuster, elytra 1.6-1.8 times as long as broad ; pronotum with a median carina ; hind femora reaching the apex of elytra ; hind tibiae straight externally and curved at the base, two basal segments of funicle subequal in length.

5( 8 ) Median carina of pronotum weak, abbreviated at least on the basal third.

6( 7) Black, with fine minute scales mixing scattered small brownish grey spots, legs almost black with a short greyish ring behind the apex of tibia.

..........................................parcimaculatus Morimoto et Miyakawa

7(6) Derm densely covered with brownish grey or ochraceous scales, mixing with small brownish and dark brownish spots on elytra, often with oblique pale band on each elytron from shoulder to basal third of suture and a transverse band behind the middle ; legs with dense greyish brown to ochreous scales, with a dark brown patch on swollen part of femora and a short patch at basal fourth of tibiae ochraceus sp. nov

$8(5)$ Median carina of pronotum evident, entire or shortly abbreviated at base.

9(10) Elytra without postmedian band, intervals without suberect scales, pronotum parallel-sided from the base to third from the apex. $\cdots$ yakushimanus sp. nov.

10( 9) Elytra with a distinct scaly band behind the middle, each interval with a row of suberect scales.

11(12) Elytra entirely black with greyish definite patches behind the middle, each interval with a row of black suberect scales on black area. $\cdots \cdots$. iriei sp. nov.

12(11) Elytra variegated with greyish, brownish and dark brown scales, each interval with a row of greyish to greyish brown suberect scales at least on declivity.

13(14) Ground scaling of femora greyish or greyish brown from the base to the 
middle, then black to apex with a greyish short ring at the swollen part in hind femora ; punctures of striae broader than intervals on the basal half of elytra. ........nipponicus Kôno

14(13) Ground scaling of femora greyish of greyish brown from the base to a little beyond the denticle or to the apex, often with blackish patch at the swollen part.

15(16) Pronotum hardly convex but slightly flattened longitudinally in the middle ; prothorax with dense fulvous or brownish scales at sides between sublateral stripes and pectoral canal excepting the basal areas ; femora with black apex and a black patch at swollen part. ........japonicus Morimoto et Miyakawa

16(15) Pronotum weakly but distinctly convex longitudinally; scales denser at apical areas of the sublateral stripes than sides.

17(18) Elytra with clear-cut subquadrate or oval punctures in striae on basal half, punctures much broader than intervals at base and as broad as intervals in the middle ; femora with blackish apex and a median patch .... * similis sp. nov.

18(17) Elytra with oval punctures in striae, punctures at most as broad as intervals at base, much narrower than intervals in the middle ; femora predominantly greyish, with brownish apex and a dark median ring or spot.

....... *yaeyamensis sp. nov.

\section{Mechistocerus rugicollis (Roelofs)}

(Figs. 1; 9A)

Monaulax rugicollis Roelofs, 1875, Ann. Soc. ent. Belg., XVIII : 163 (Japon). -Hustache, 1936, Col. Cat., Pars 151, Cryptorrhynchinae : 239 (Japon). -Morimoto, 1962, Sci. Bull. Fac. Agr., Kyushu Univ., 19: 352 (Honshu, Shikoku).

Mecistocerus rugicollis : Morimoto, 1984, Coleopt. Jap. in color, IV: 331, pl. 65. fig. 21 (Honshu, Shikoku, Kyushu).

Male. Derm dull black, with antennae and tarsi reddish brown; pronotum with an indefinite patch of fulvous scales on each side of the front margin ; elytra mottled with black, brown and grey, with a broad greyish band behind the middle.

Head with dense punctures, each puncture bearing a fulvous scale, median fovea ovate, a little longer than broad. Rostrum not constricted laterally at the base, which is punctate like head, with five dorsal carinae, median carina shiny, admedian carinae weak, undulate, both carinae present on basal half, lateral carinae on basal third indefinite, dorsal margin of scrobe carinate, directing to the top of eye, disk being shiny, sparsely punctate leaving bare mesial area before the middle. Antennae inserted in the middle of rostrum, scape coriarious, funicle pubescent and setose, first segment $5 / 4$ times as long as second, twice as long as third, sixth segment as long as wide, seventh segment transverse, club slightly shorter than first and second segments of funicle combined, about twice as long as broad, first segment as long as broad, second segment transverse, suture between them transverse.

Prothorax a little broader than long (11:10), parallel-sided from the base to the middle, then narrowing to the shallow subapical constriction, dorsum gently convex longitudinally, with oval deep punctures, in fresh specimens the punctures visibly smaller and separated, but these are reticulately provided when scraped, lateral areas 


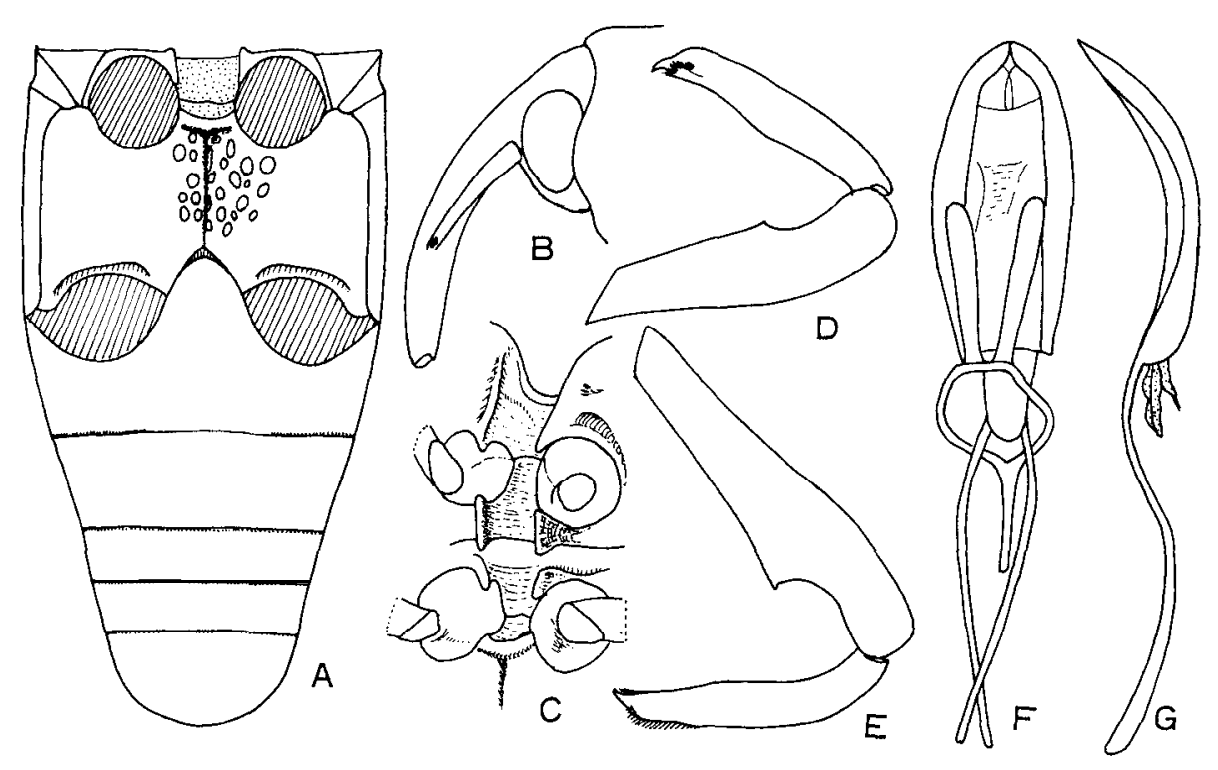

Fig. 1. Mechistocernus megicollis (Roelofs), Љ . A : Pterothorax and abdomen, ventral. B : Head, lateral. C : Pectoral canal. D : Fore leg. E : Hind leg. F : Penis, dorsal. G : Ditto, lateral.

with larger and honeycomb punctures, the punctures smaller and denser before subapical constriction. Scutellum oval, convex, with several small punctures, each puncture with a small recumbent greyish scale in fresh specimens.

Elytra twice as long as broad, subcylindrical from humeri to apical third, striae with deep punctures that diminish behind, dense at base and separated by about their own length at the middle, intervals subconvex and rugose at base, flat and broader than striae behind the basal third; scaling variable, basal margin and median transverse area darker, dorsal area before the darker median area mottled with brown and grey, postmedian greyish band variable in shape.

Pectoral canal reaching the middle of middle coxae, metasternal receptacle not prominent ventrally, weakly hollowed ; metasternum opaque laterally and shiny in the middle, reticulately punctate, median sulcus narrow, terminated anteriorly by a deep puncture just behind receptacle. Venter shiny, first ventrite depressed in the middle, punctures a little smaller and sparser than those on metasternum, third and fourth ventrites with small shallow punctures, with irregular 445 rows of punctures and scales in the middle, fifth ventrite with distant deep punctures.

Legs rather stout, femora evenly dilated from the base to the dentate portion, not forming distinct stalk, hind femora reaching the middle of fifth ventrite, tibiae bisinuate internally, their expansion being at just proximal to the middle in fore, at the middle in middle and at apical third in hind tibiae.

Aedeagus with median lobe rather thin, broadest at apical third, membranous ventrally, internal sac without sclerite.

Female. Rostrum with an abbreviate median and punctate like head at 
base, lateral areas above scrobes subsulcate with punctures, the remaining area with sparse small punctures. Antennae inserted just behind the middle of rostrum. First ventrite convex ventarally.

Length : 4.2-7.7 $\mathrm{mm}$.

Specimens examined : 31 exs. from Aomori, Nagano, Kyoto, Nara, Osaka, Kochi, Fukuoka, Kumamoto Prefs. and Taiwan (Taiheizan).

Distribution : Japan (Honshu, Shikoku, Kyushu), Taiwan.

This species is similar to M.integrirostris Marshall from Burma in having the subcylindrical body and the not constricted rostrum at the base, but is easily separable from it by the elytra being not produced downwards at the apex in the female, presence of the fovea on the forehead and larger size. This is also similar to M.subcylindricus Faust from Burma, but the pectoral cannal of the latter is reaching the posterior margin of the mesocoxae and the fovea on the forehead is narrower.

\section{Mechistocerus okumai sp. nov.}

(Figs. $2 ; 9 \mathrm{~B}$ )

Female. Derm black, with antennae and tarsi reddish brown; scaling bicoloured, orange brown scales covering head, base of rostrum, anterior third of pronotum, postmedian band and small indefinite patches on elytra, basal three-fourths of femora and apical halves of tibiae, underside with scales of the same colour, the other areas with blackish scales.

Head with dense punctures, forehead with an oval fovea. Rostrum not constricted laterally at the base, punctate and scaled like head at base, with three shiny carinae on basal third, median carina reaching fovea, admedian carinae abbreviated at base, latero-dorsal areas between the admedian and the lateral carinae along dorsal margin of scrobes each with irregular two rows of punctures, the other area with small sparse punctures, antennal scrobes with its dorsal margins directing to the top of eyes. Antennae inserted in the middle of rostrum, scape clavate at apical fourth, funicle pubescent and setose, first segment $5 / 4$ times as long as second and twice as long as third, fourth segment as long as broad, fourth to seventh successively broader, club compact, much shorter than first and second segments of funicle combined.

Prothorax slightly broader than long $(12: 11)$, broadest near the base, evenly and weakly narrowing anteriorly in a curve to obsolete subapical constriction, disk weakly convex longitudinally, with dense deep oval punctures like in rugicollis, lateral areas with honeycomb larger punctures, the punctures smaller before subapical constriction, median carina obsolete. Scutellum subtrapezoid, convex, with several small punctures and a few setae.

Elytra about twice as long as broad, subcylindrical from the rectangulary rounded shoulders to the apical third, striae narrow and deep at base, then as broad as intervals to the postmedian band, with oval punctures, their septa much narrower than their length, and diminish behind, each puncture with a few small scales, intervals flat, without elect large scale, lateral margin with a small notch at antero-dorsal corner of metepisternum, weakly produced downwards at apex.

Pectoral canal and underside as in rugicollis.

Legs with fore and middle femora almost parallel-sided on basal third, hind 

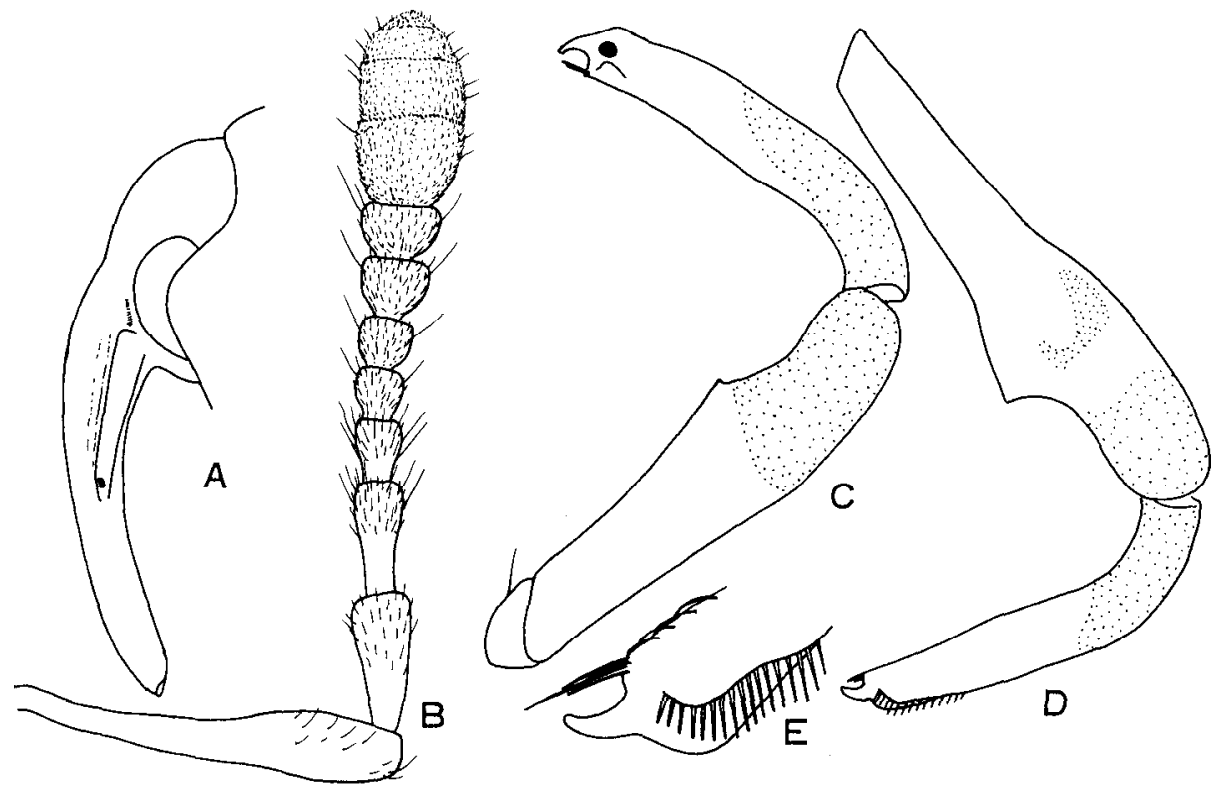

Fig. 2. Mechistocerus okumai sp. nov., ㅇ. A : Head, lateral. I3 : Antenna. C : Fore leg. D: Hind leg. E: Apex of hind tibia.

femora reaching the middle of fifth ventrite, parallel-sided to the middle, then weakly swollen. Tibiae curved at basal third, slightly bisinuate internally, each uncus originate from the middle of the apical margin.

Male. Unknown.

Length : $9.5 \mathrm{~mm}$.

Holotype female (Type No. 2588, Kyushu Univ.), Yuwangama-rindo, AmamiOshima, 7. v. 1976, J. Okuma leg.

Distribution : Japan (Amami-Oshima 1.).

This most resembles M.rugicollis, but the latter differs in having the greyish scaly patches, the dorsal carinae of rostrum are much shorter and weaker, and the tibiae are distinctly bisinuate internally. The name is dedicated to Mr. Jun Okuma, who found this interesting species.

\section{Mechistocerus parcimaculatus Morimoto et Miyakawa}

(Fig. 9C)

Mecistocerus parcimaculatus Morimoto et Miyakawa, 1985, Mushi, 50:53, figs. 18C \& 20 (Yaku I. and Hachijo I.).

Male. Derm black, antennae and tarsi reddish brown; prothorax almost bare, with a dark brown scale at the posterior margin of each puncture ; elytra with small dense blackish scales mixing sparse ochreous grey scales, these forming scattered small patches, each interval with a row of widely separated scales, these are twice as 
large as ground scales, blackish in blackish area and ochreous grey in ochreous grey scaled area ; ground scaling of femora blackish, often with greyish small patch at dorsal side above tooth in the middle and hind femora, tibiae blackish with ochreous grey scales at apical third; lateral and undersides with sparse scales, venter with small dense blackish scales mixing a few greyish scales.

Head rugulose, opaque, with a deep fovea, which is broad in front and narrows to a point behind, vertex with large punctures and shiny. Rostrum a little broader at the base than the minimum distance of eyes, with five carinae at basal third, median carina shiny, distinct, two dorsolateral carinae weak, shiny with minute sparse punctures before the middle. Antennae inserted in the middle of rostrum, first segment of funicle as long as second, sixth segment as long as broad, seventh segment a little broader than long.

Prothorax transverse (6:5), parallel-sided in the basal half, disk weakly convex longitudinally, with large deep reticulate punctures, the punctures a little smaller anteriorly, trace of a median carina present before the middle. Scutellum trapezoidal, widest behind, convex, shiny, bare.

Elytra about 1.6 times as long as broad, parallel-sided from humeri to the middle, striae with subrectangular punctures on basal third, the septa as high as intervals and much shorter than their length, then gradually narrowing posteriorly.

Pectoral canal reaching the posterior margin of metacoxae, receptacle evenly concave, marginate posteriorly, slightly prominent ventrally; median sulcus of metasternum dilated posteriorly, terminated anteriorly by a deep puncture. Venter opaque, first ventrite and sides of second ventrite with large punctures, fifth ventrite with scattered shallow indefinite punctures, the rest with minute punctures.

Femora clavate, with large triangular tooth overlapped by ochreous scales, tibiae almost straight, weakly curved internally at the apex and the base.

Aedeagus with penis rounded at apex, internal sac with a small forked sclerite at gonopore.

Female. Median carina of rostrum present on basal fourth, antennae inserted into just behind the middle of rostrum, first ventrite not depressed.

Length : 5.4-8.6 mm.

Specimens examined : Mt. Takahachiyama, Tottori Pref., $1 \sigma^{71} \mathrm{l}$ 우, 5. vi. 1982, 0. Yamaji leg. Mihara-rindo, Hachijo I., 1॰7, 22. iv. 1978, S. Miyakawa leg. (Paratype). Mt. Tachudake, Yaku I., 1이우, 20. vii. 1971, H. Irie leg. (Holo-and paratypes). Hananoego, Yaku I., 1 우, 14. vii. 1961, K. Ueda leg. (Partype). Shiratani-rindo, Yaku I., 1우, 19. vii. 1976, M. Kaneda leg.

Distribution : Japan (Honshu, Hachijo I., Yakushima I.).

This species is easily recognized by the obsolete median carina and visibly blackish derm with scattered small ochreous grey patches on elytra. The punctures on the pronotum are almost as long as or slightly longer than broad and arranged reticulately or honeycombed. The male aedeagus was already illustrated in the original description. 


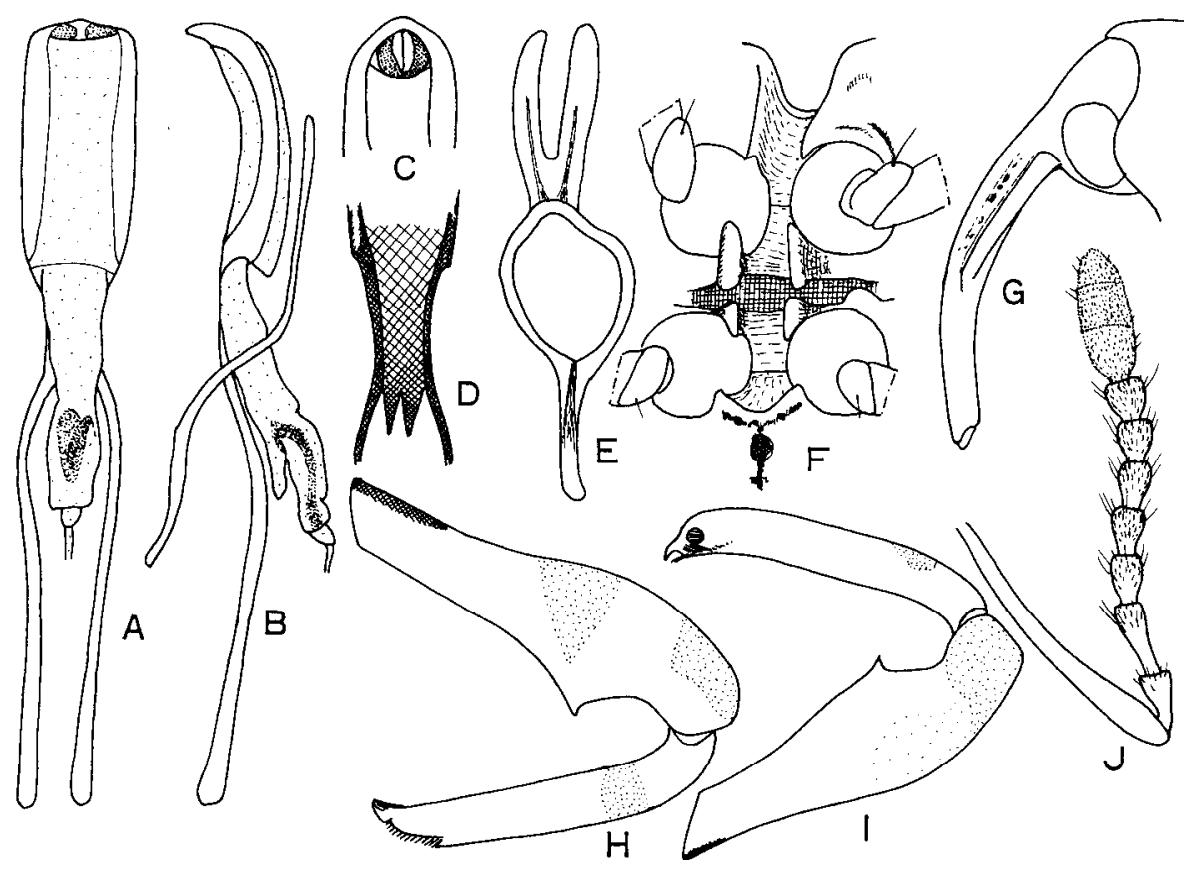

Fig. 3. Mechistocerus ochraceus sp. nov., ơ. A : Penis, dorsal. B : Ditto, lateral. C : Apex of penis. D : Basal part of penis, ventral. E : Tegmen and parameres. F : Pectoral canal. G : Head, lateral. H : Hind leg. I : Fore leg. J : Antenna.

\section{Mechis tocerus ochraceus sp. nov.}

(Figs. 3 ;9D)

Male. Derm black, antennae and tarsi dark reddish brown; scaling predominantly ochreous above, paler and greyish scales forming following patches, three stripes on pronotum, basal patches of second and third intervals, an oblique band from shoulder to just before the middle of suture, and a transverse indefinite band on apical third; dark brown to blackish scales forming irregular small patches on elytra, variable in shape and number; underside with brownish grey scales; legs with brownish grey scales, femora with brownish two rings or patches, one at apex, the other above tooth, tibiae each with a dark brown ring a little before the base.

Head densely punctate, completely concealed by brown scales, vertex densely punctate, coriarious, forehead between eyes a little narrower than the base of rostrum, median fovea $5 / 2$ times as long as broad, triangular, broad in front. Rostrum evenly curved, with three carinae on basal half, median carina sharp, shiny, dilated in the middle of rostrum, lateral carinae broad, with a row of shallow puncures, dorsal and lateral surfaces before the middle with distant small punctures. Antennae inserted at the middle of rostrum, scape clavate at apex, funicle with first segment as long as (in small specimens) or $7 / 6$ times as long as second (in large specimens), with several 
recumbent setae, second to seventh segments pubescent and setose, third segment $2 / 3$ times as long as second and as long as fourth, seventh segment slightly longer than broad, club compact, twice as long as broad.

Prothorax transverse $(7: 5)$, broadest just before the base, narrowing in a curve to the shallow apical constriction ; disk scarcely convex longitudinally, with large deep reticulate punctures, which are smaller anteriorly before the subapical constriction, each puncture with an oval scale, median carina rarely present on anterior two-thirds. Scutellum transverse-oval, convex, with sparse small punctures and short setae.

Elytra 1.52-1.67 times as long as broad, relatively broader in larger specimens, parallel-sided from the roundly rectangular shoulders to the middle; in fresh specimens striae visibly much narrower than intervals, punctures oblong oval, each with an oval scale, septa as long as their length; in scraped specimens, striae with large rectangular punctures, the septa much shorter than their length, and intervals granulate on basal half; intervals each with a row of larger scales (indistinct in large specimens).

Pectoral canal almost reaching the posterior margin of hind coxae, receptacle marginate posteriorly, slightly prominent ventrally. Metasternum with a median sulcus terminating anteriorly by a large puncture, with large punctures, each puncture with a scale, which is longer and slenderer in the middle. Venter punctate and scaled like sides of metasternum, median depressed part of first ventrite with small scales on interstices and narrower scales in punctures, third and fourth ventrites each with a row of large punctures.

Legs with femora clavate, dentate. Tibiae very weakly bisinuate, produced internally behind the middle in fore tibiae and produced at the middle in middle and hind tibiae.

Aedeagus as figured, penis strongly bent at apex, ventral lobe of internal sac with dense asperities and visibly brownish, without sclerite.

Female. Rostrum carinate on basal third ; antennae inserted behind the middle of rostrum ; first ventrite not depressed, evenly scaled and punctate as sides.

Length : 3.9-10.8 $\mathrm{mm}$.

Holotype male (Type No. 2589, Kyushu Univ.), Shikina, Naha, Okinawa I., 29. iv. 1982, K. Iha leg.

Paratypes : Same data as holotype, $5 \sigma^{7} 7$ 우. Naha, Okinawa I., 18, 1. vi. 1976, T . Ogasawara leg. Shuri, Okinawa I., 16, 9. vi. 1961, O. Nakachi leg. ;1 ð, 23. v. 1962, M.

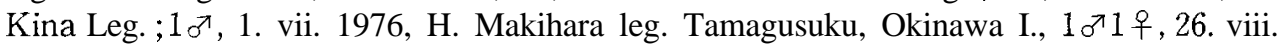
1962, M. Kina leg; $1 \sigma^{7}$, ix. 1962, M. Kina leg. Koza, Okinawa I., 1 우, 10. vi. 1970, Y. Miyake leg. Minamimeijisan, Okinawa I., 1 $\sigma^{7}$, 23. viii. 1963, M. Okabe leg. Kudeken, Chinen-son, Okinawa I., 1우, 22. iv. 1975, H. Irie leg. Hirara, Miyako I., 1 ㄲ1우, 17. viii. 1969, H. Makihara leg. Shokubutsuen, Miyako I., 3 $\sigma^{7}$, 29. vi. 1974, S. Kimoto leg. Shiokawa, Tarama I., 1ऽ 10. ix. 1979, J. Okuma leg. Ishigaki I., $2 \sigma^{\Im} 3$ 우, v-vii. 1938, Masaki, Senaha, Ohshima \& Ikeda leg. ; $4 \sigma^{-1} 4$ 우, 22. V. 1962, K. Kojima leg. ;1 $1 \sigma^{7}, 16$. vii. 1962, Y. Hama leg. ; $10^{71}$ 우, 13. v. 1973, I. Fujiyama leg. Mt. Bannadaka, Ishigaki I., 1 우, 30. iii. 1974, T. Takahashi leg. ;1우, 28. v. 1974, J. Okuma leg. ;1 이우, 13 \& 21. vi. 1974, T. Mikage leg. Iriomote I., 1 우, 12. iv. 1975, S. Yamauchi leg. ; Ohara, Iriomote I., $28^{7}, 9$ \& 17. viii. 1962, M. Chujo leg.; 1 ㅇ, 7. v. 1973, I. Fujiyama leg. Sonai, Iriomote I., $5 \delta^{7} 2$ 우, 28. v. 1977, J. Okuma leg. Hateruma I., 161 우, 22. vi. 1977, H. Irie leg. Sonai, 
Yonaguni I., $1 \sigma^{7}$, 14. vii. 1976, S. Kimoto leg. Hori, Taiwan, $2 \sigma^{7}, 24 \&$ 28. vi. 1965, T, Shirozu leg. Jibbon Spa, Taiwan, $1 \diamond^{\nearrow}, 2$. iv. 1970, Y. Miyake leg. Kenting Park, Taiwan, 2 ㅇ, 14 \& 17. v. 1978, T. Senoh leg. Kuraru, Taiwan, 1우,1.ix. 1921, T. Esaki leg. Kotosho, 1 우, 13. viii. 1968, H. Makihara leg.

Distribution : Japan (Okinawa, Tarama, Miyako, Ishigaki, Iriomote, Hateruma, and Yonaguni Isls.), Taiwan, Lanyu I.

This new species belongs to Heller's Mechistocerus, of which the receptacle reaches the posterior margin of hind coxae, but separable from the species of this genus enumerated by Heller (1921) by the shape of pronotum, granulate intervals of the elytra, and the scaly patterns. This is similar to M.mubilosus Boheman, 1844, from Timor and Java in having the similar pronotum and the scaly patterns, but the prothorax is apparently narrower than the elytra. The latter species is now placed in Coelosternus but actually a species of the genus Mechistocerus.

The adults were captured on the stem of dead Erythrina variegata (Deigo in Japanese), and are attracted to light at night.

\section{Mechistocerus yakushimanus sp. nov.}

(Figs. 4 ;9EF)

Male. Derm black, with antennae and tarsi reddish brown, mottled with black, brown and grey ; scaling much less dense on pronotum ; pronotum with three brownish stripes mixing grey, and a pair of median small spots ; elytra without band, second and third intervals often greyish at bases.

Head with dense punctures, completely concealed by brown scales, vertex bare, shiny, with larger punctures, forehead between eyes slightly narrower than the base of rostrum, with a suboval deep fovea. Rostrum evenly curved, weak median carina on basal third, lateral carina parallel to median carina on basal third, then weakly diverging anteriorly and conjoined with marginal carina at the middle above antennal socket, densely punctate on basal half, sparsely puncticulate on apical half. Antennae inserted at the middle of rostrum, scape clavate at apex, funicle setose and pubescent from second to seventh segment, first segment with a few decumbent setae, equal to second in length, fourth segment $3 / 2$ times as long as broad, fifth to seventh segments subglobular, fifth segment as long as broad, sixth and seventh transverse, club compact, twice as long as broad.

Prothorax a little broader than long $(11: 10)$, parallelsided or very slightly narrowing from the base to apical third, then narrowing in a curve to weak subapical constriction; disk scarcely convex longitudinally, with large deep honeycomb punctures as on sides, each puncture with a small narrow scale at the posterior corner, median carina shiny in entire length. Scutellum subtrapezoidal, convex, shiny, finely pubescent on latero-posterior surface.

Elyra 1.60-1.78 times as long as broad, relatively slenderer in smaller specimens, parallel-sided from the roundly rectangular shoulders to two-thirds, posterior calli low but distinct, striae with elongate punctures, each without scale, septa as high as intervals, diminishing behind, intervals weakly convex at base, third interval weakly costate at base, each without suberect scale.

Pectoral canal almost reaching the posterior margin of hind coxae, receptacle not 


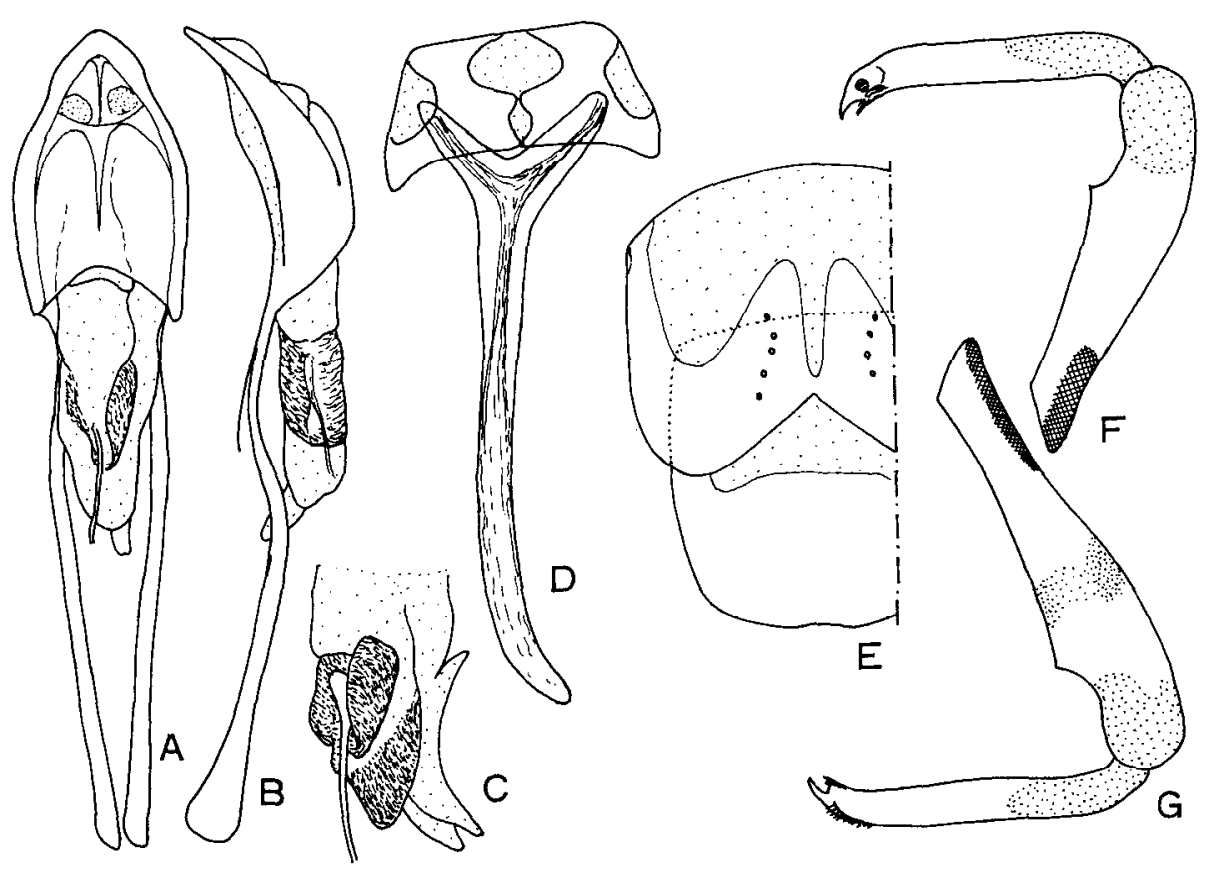

Fig. 4. Mechistocerus yakushimanus sp.nov., o. A : Penis, dorsal. B : Ditto, lateral. C: Gonopore. D : Genital segment. E : Pygidium and propygidium, showing the ar. rangement of scrapers. F : Fore leg. G : Hind leg.

prominent ventrally ; metasternum opaque laterally, median area of metasternum and first ventrite depressed, shiny, with separate deep punctures, each with a suberect scale, interstices finely coriarious, with short decumbent sparse scales; lateral area of metasternum and venter with brownish or ochreous scales, median area of third and fourth ventrites visibly dark brown.

Legs with brownish or ochreous scales, apical part of femora and basal third of tibiae blackish, middle and hind femora each with a blackish ring at swollen part. Tibiae straight externally, slightly bisinuate internally.

Aedeagus with penis broadest in the middle and rapidly narrowing apically, internal sac with dense brownish asperities around gonopore, without sclerite.

Female. Rostrum with weak carinae and punctures at the base, the punctures diminishing anteriorly and almost impunctate before the middle. First ventrite not depressed.

Length : 6.7-10.9 mm.

Holotype male (Type No. 2590, Kyushu Univ.), Miyanoura, Yaku-shima I., 29. vii. 1974, T. Mikage leg.

Paratypes : Same locality as holotype, $2{ }^{7} 15$ 우, 27-29. vii. 1974, T. Mikaege leg. Kosugidani, Yakushima I., 1우, 18. vii. 1950, T. Shirozu leg. ;1우, 14. vii. 1968, K. Suga leg. ;1 ð7, 12. vii. 1961, K. Ueda leg. ; 26, 2. vi. 1969, H. Makihara leg, ;5 ㄲ6우, 19-24. vii. 1974, T. Mikage leg. Ambo, Yakushima I., $1 \delta^{71} 1$ ㅇ, 15. vii. 1950, T. Shirozu leg. 
Shiratani, Yakushima I., $40^{7} 5$ 우, 24-26. vii. 1974, T. Mikage leg. Mt. Tachudake, Yakushima I., 1ऽ, 20. vii. 1971, H. Irie leg.

Distribution : Japan (Yakushima I.).

This species differs from the other Japanese species by the scarcely convex pronotum, lack of the suberect scales on the intervals, lack of the postmedian band on the elytra, and shape of the penis.

Mechistocerus iriei sp. nov.

(Figs $5 ; 10 \mathrm{~A}$ )

Male. Derm black, with antennae, apical part of rostrum and tarsi reddish brown ; scaling black with following greyish patches, pronotum with an antescutellar small patch and a pair of lateral stripes, which are often separated into anterior and posterior spots, elytra with a pair of definite large patches between first and eighth striae behind the middle, the patch fringed with a row of brownish scales, second and third intervals with indefinite small patches.

Head completely concealed by blackish scales, with a small greyish spot in the middle behind subtriangular fovea, and brownish scales on each side along eye, vertex bare, with dense punctures, forehead between eyes slightly narrower than the base of rostrum. Rostrum evenly curved, with three carinae on basal half, median carina shiny, definite, lateral carinae broad containing a row of shallow punctures on basal fourth, apical half with sparse minute punctures. Antennae inserted at the middle of rostrum, scape clavate at apex, first segment of funicle as long as second, third segment $2 / 3$ times as long as second and $10 / 7$ times as long as fourth, sixth segment as long as broad, seventh segment slightly broader, club compact, three times as long as broad.

Prothorax transverse $(6: 5)$, parallel-sided from the base to the middle, then narrowing in a curve to weak subapical constriction, weakly convex longitudinally ; disk opaque, with dense deep honeycomb punctures, interstices with dense small black scales, each puncture with a suberect black scale at posterior corner, which is not or only slightly longer than those on interstices, median carina shiny, abbreviated at basal third, often obsolete at subapical constriction, sides strongly punctate like disk, but interstices not scaled. Scutellum subtrapezoidal, convex, shiny, with a few small setae.

Elytra 1.51-1.57 times as long a broad, parallel-sided from rectangularly rounded shoulders to the middle, subapical calli low but distinct, striae with oval punctures, septa as long as their length, as high as intervals, diminishing behind, each puncture with a small black scale, but indistinct, intervals with dense scales, each with a row of distant suberect scales, which are not larger than ground scales, inconspicuous and only observed under high magnification.

Pectoral canal ending shortly before the posterior margin of hind coxae, receptacle weakly prominent ventrad. Metasternum coriarious, with large punctures, median sulcus terminated anteriorly by a transverse deep depression behind receptacle. First and second ventrites near sides at posterior margin and third and ourth ventrites at sides with brownish grey scaly spots, first and fifth ventrites with deep large punctures, second to fourth ventrites without large punctures, coriarious, with black small scales, fifth ventrite with pale brown suberect long scales in the middle. 


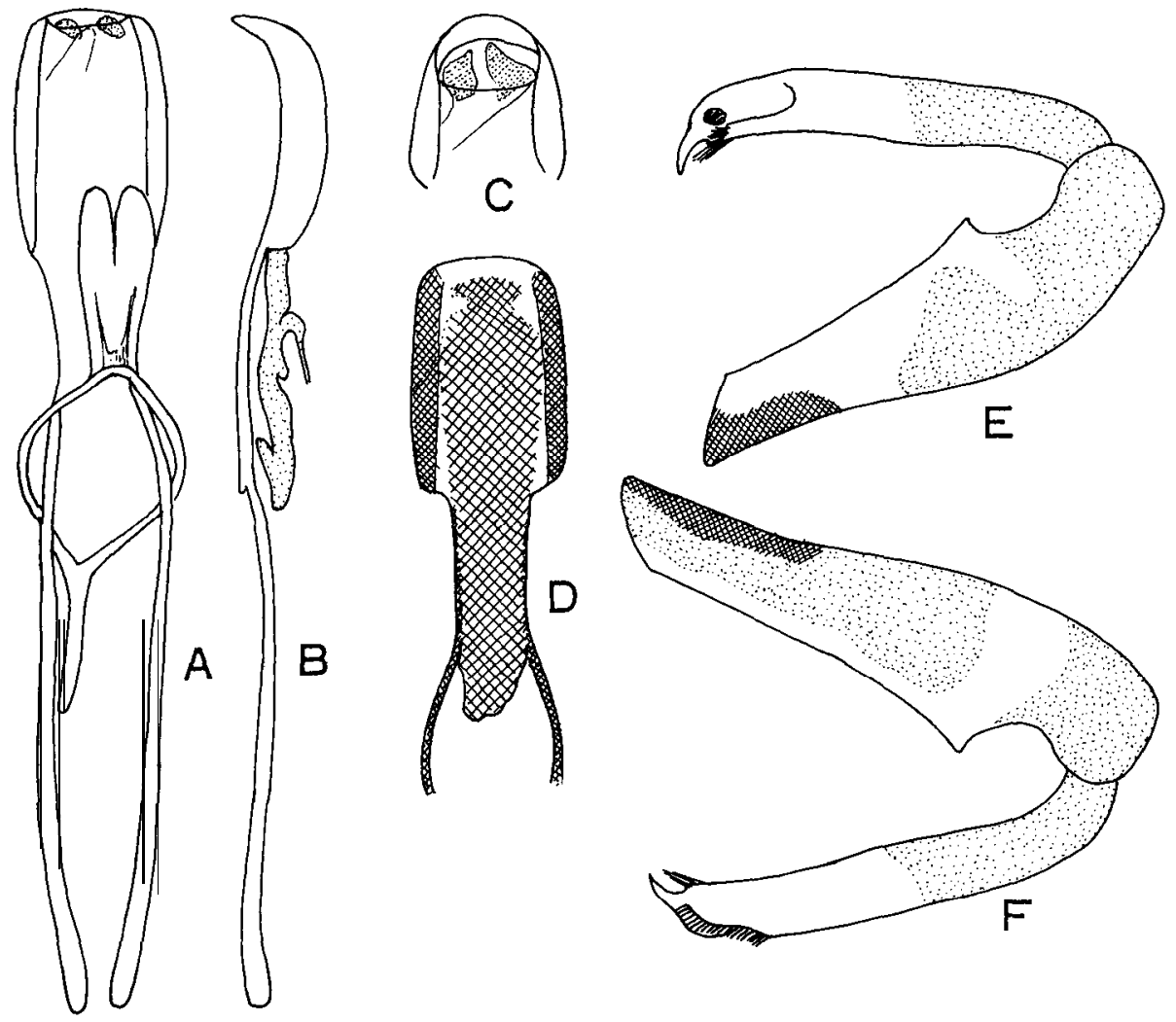

Fig. 5. Mechistocerus iriei sp. nov., ơ A : Penis, dorsal. B : Ditto, lateral. C : Apex of penis. D: Penis, ventral. E: Fore leg. F: Hind leg.

Legs with femora clavate, fore femore greyish or brownish grey from the base to the middle, then blackish distally, middle and hind femora blackish with greyish to brownish grey posterior margin from the base to tooth and a greyish ring at tooth, punctures at blackish area each with a greyish scale. Tibiae straight externally, weakly incurved at apex, weakly bisinuate internally, blackish from the base to the middle, then greyish to apex.

Aedeagus with penis subparallel-sided, strongly bent at apex, internal sac without sclerite.

Female. Rostrum with carinae on basal fifth ; antennae inserted at just behind the middle of rostrum ; elytra not produced downwards at apex ; first ventrite not depressed.

Length : 6.7-10.8 $\mathrm{mm}$.

Holotype male (Type No. 2591, Kyushu Univ.), Nakanoshima I., Tokara Isls., 1-2. v. 1975, H. Irie leg.

Paratypes : Same locality as holotype, $7 \sigma^{7} 6$ 古, 25. iv-2. v. 1975, H. Irie leg. ; $1 \diamond^{7}$, 5. vii. 1960 , M. Sato leg. 
Distribution : Japan (Tokaras : Nakanoshima I.).

This species is easily recognized by the greyish definite patches on the black elytra.

\section{Mechistocerus nipponicus Kôno}

(Figs. 6; 10B)

Mechistocerus nipponicus Kôno, 1932, Ins. mats., VI : 180 (Sapporo, Moiwa, Jozenkei, Berg Daisetsu, Chuzenji, Berg Takao, Berg Sanjodake). -Kôno, 1950, Icon. Ins. Jap., ed. sec. : 1277, fig. 3681 (Hokkaido, Honshu). -Morimoto, 1962, Sci. Bull. Fac. Agr., Kyushu Univ., 19 : 352 (Hokkaido, Honshu, Shikoku, Kyushu). -Nakane. 1963. Icon. Ins. Jap. col. nat. ed., II : 370, pl. 185, fig. 18.

Mecistocerus nipponicus : Voss, 1958, Decheniana, Beih. 5 : 52 (comp. w. fukienensis). -Morimoto, 1984, Coleopt. Jap. in col., IV : 332, pl. 65, fig. 22.

Male. Derm black, opaque, with dark reddish tarsi and antennae; scaling predominantly blackish, pronotum with a pair of rather narrow indefinite sublateral stripes of fulvous scales, elytra with variable small spots and a postmedian indefinite broad band of fulvous to brownish scales.

Head with dense punctures and scales, scales greyish brown at periphery and on a median stripe, the rest blackish brown, forehead between eyes slightly narrower than the base of rostrum, with an oval deep fovea, which is twice as long as broad, vertex bare, with large punctures, interstices rugose. Rostrum evenly curved, with a shiny median and a pair of lateral weak carinae on basal third, punctate from the base to basal third, then sparsely puncticulate anteriorly. Antennae inserted at the middle of rostrum, first segment of funicle as long as second and 1.5 times as long as third, sixth segment as long as broad, seventh segment transverse, club 2.5 times as long as broad.

Prothorax 1.09-1.18 times as broad as long, broadest at the middle and weakly narrowed posteriorly or parallel-sided from the base to the middle, then narrowing in a curve to weak subapical constriction, weakly convex longitudinally, disk with large deep punctures, interstices a little narrower than their diameters, each puncture with a small dark scale, median carina shortly abbreviated at base. Scutellum subtriangular, convex, shiny, with sparse pubescence.

Elytra $5 / 3$ times as long as broad, parallel-sided from rectangularly rounded shoulders to the middle, striae diminished behind the middle, with oblong punctures, septa as high as intervals, a little shorter than their length on basal half, each puncture with an inconspicuous small scale, intervals without suberect scales on basal half, each with a row of inconspicuous small suberect scales behind the middle.

Pectoral canal reaching the posterior $1 / 3$ of hind coxae, receptacle weakly prominent ventrad. Metasternum opaque and with shallow large punctures at sides, shiny and distant punctures in the middle, median sulcus terminated anteriorly by a deep depression behind receptacle. Venter with a pair of stripes of fulvous scales behind hind coxae to sides of fourth ventrite, first ventrite with deep punctures along anterior margin, the rest and second ventrite with small distant punctures, third and fourth ventrites visibly impunctate, fifth ventrite with distant deep punctures.

Legs with femora clavate, fulvous from the base to the middle, then black to apex. Tibiae slightly bisinuate, black from the base to the middle, then greyish or fulvous to apex. 


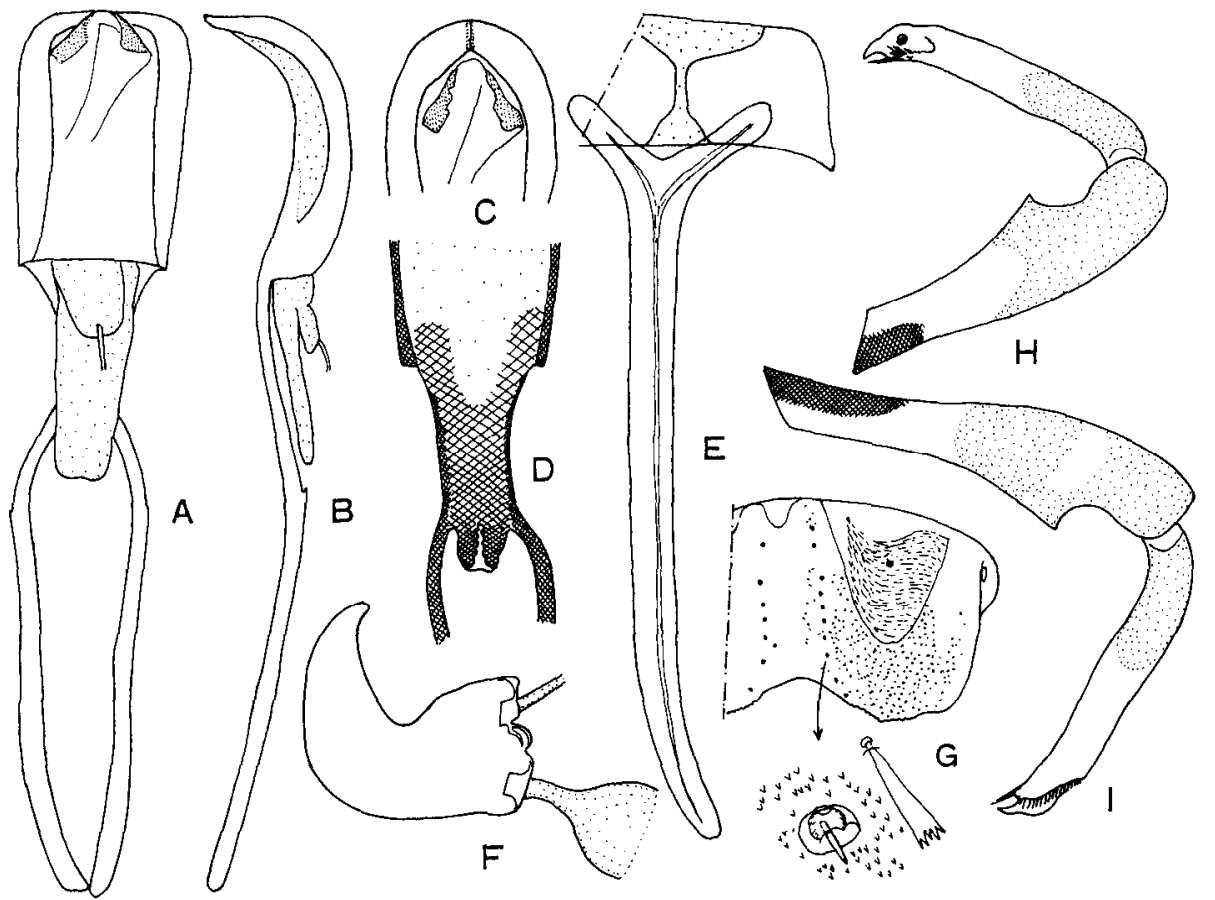

Fig. 6. Mechistocernes nipponicus Kôno, ơ (except F 우). A : Penis, Dorsal. B : Ditto, lateral. C : Apex of penis. D: Basal part of penis, ventral. E: Genital segment. F: Spermatheca. G: Propygidium (7th tergite) and a scraper, enlarged. H : Fore leg. I: Hind leg.

Aedeagus with penis parallel-sided and strongly vent at apex, internal sac without sclerite.

Female. Rostrum with short weak carinae at the base, with two rows of punctures between the carinae ; antennae interted just behind the middle of rostrum ; first ventrite not depressed.

Length :6.6-11.5 mm.

Specimens examined: 91 specimens from Hokkaido, Aomori, Niigata, Fukushima, Tochigi, Tokyo, Nagano, Shizuoka, Nara, Osaka, Wakayama, Okayama, Tokushima, Kochi, Ehime, Fukuoka, Kumamoto, and Oita Prefs., Sado I.

Distribution : Japan (Hokkaido, Honshu, Shikoku, Kyushu, Sado I.).

This species is distinguished from the other Japanese species at first sight by the predomiantly blackish pronotum, indefinite postmedian band on the elytra and the blackish femora on the distal half, The interstices among punctures on the pronotum are a little narrower than the diameter of the punctures and opaque.

Adults are commonly found on the dead trunk of the broadleaved trees in summer. 


\section{Mechistocerus yaeyamensis sp. nov.}

(Figs. 7; 10C)

Male. Derm black, antennae reddish brown, apical part of rostrum and tarsi dark reddish brown, mottled with black, brown and grey ; pronotum with a pair of greyish to brownish sublateral stripes, median area on each side of the carina and latero-dorsal area with brownish scales, which denser before the subapical constriction, often with an indistinct antescutellar short greyish stripe ; elytra with a greyish broad postmedian band with its margins irregular and usually interrupted at suture.

Head with dense punctures, completely concealed by yellowish grey scales, vertex bare, with dense punctures, rugose, forehead between eyes distinctly narrower than the base of rostrum, with a subtriangular deep fovea, which is 1.5 times as long as broad and pointed posteriorly. Rostrum evenly curved, gradually tapering apically in lateral aspect, with three sharp carinae and dense punctures from the base to the middle, then sparsely puncticulate to the apex, apical area flattened dorso-ventrally, scarcely punctate. Antennae inserted at the middle of rostrum, scape clavate at apex, funicle setose and pubescent, the pubescence denser from third to seventh segments, first segment as long as second and $2 / 3$ times as long as third, fifth segment as long as broad, globular, seventh segment transverse, a little broader than sixth, club compact, 2.2 times as long as broad, first segment half as long as club.

Prothorax 1.1-1.2 times as broad as long, parallel-sided from the base to the middle, then narrowing in a curve to weak subapical constriction, disk weakly convex longitudinally, disk and sides with large punctures, interstices opaque, a little narrower than their diameters, but partly covered by scales, each puncture with an indefinite small suberect scale, median carina shortly abbreviated at base. Scutellum trapezoidal, convex, shiny, with a few small punctures and short scales.

Elytra $5 / 3$ times as long as broad, broadest a little behind humeri, or subparallelsided from the base to the middle, striae narrower than intervals, punctures oblongoval, larger at the base and diminished behind, septa about as long as their length, each puncture with an oval greyish to brownish grey scale of the similar size to those on intervals, third and fifth intervals slightly convex at base, each interval with a row of suberect scales, which are a little longer than decumbent ones.

Pectoral canal reaching the posterior quarter of hind coxae, receptacle weakly concave, not prominent ventrally. Metasternum opaque, with distant large punctures, scaled at sides like elytra, with small sparse scales in the middle, median sulcus terminate anteriorly by a deep fovea, which extending laterally to form a transverse sulcus behind receptacle. Venter with dense yellowish brown scales at sides and blackish to dark brownish scales in the middle, first ventrite punctate and scaled like metasternum, flat, second ventrite with shallow distant punctures in the median dark area, third and fourth ventrites impunctate, fifth ventrite with deep punctures.

Legs with femora clavate, fore and middle femora with brownish grey to greyish scales, with brownish rings at the middle and apex, hind femora with predominantly brownish grey to greyish scales, with a dark patch in the middle and a brownish to dark brownish indefinite ring behind the apex. Tibiae slightly bisinuate, with blackish scales from the base to the sinuate posrtion near the middle, then greyish to apex.

Aedeagus with penis evenly vent, subparallel-sided, anterior margin between 

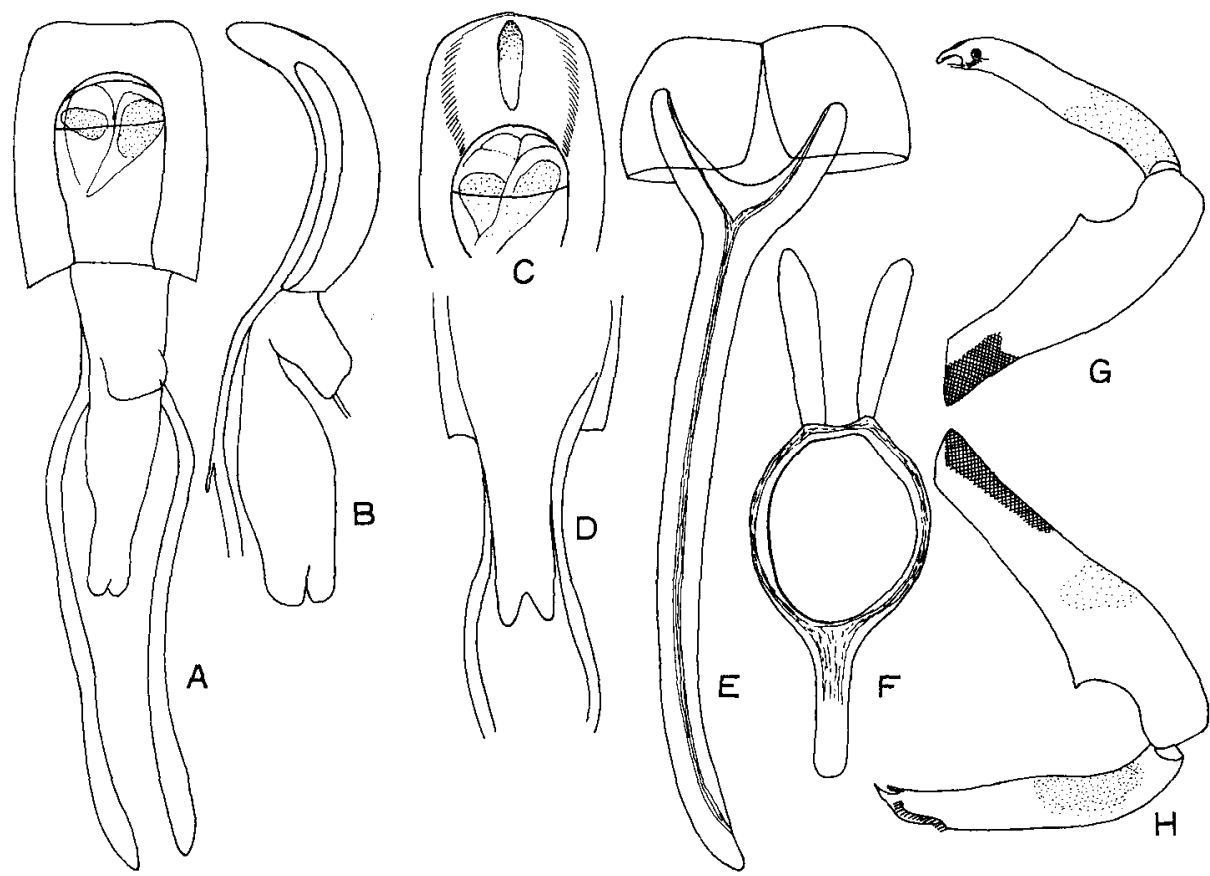

Fig. 7. Mechistocerus yaeyamensis sp. nov., ơ A : Penis, lateral. B : Ditto lateral. C : Apex of penis. D : Basal part of penis, ventral. E : Genital segment. F : Tegmen and parameres. G : Fore leg. $\mathrm{H}$ : Hind leg.

ostium and apex much wider than lateral margin in dorsal aspect and with a lesspigmented median stripe, internal sac without sclerite.

Female. Rostrum with median carina on basal quarter, lateral carinae weak, punctate between carinae and above scrobes, with fine punctures before the middle. Antennae inserted in the middle of rostrum.

Length : 6.8-9.5 mm.

Holotype male (Type No. 2592 Kyushu Univ.), Yoshihara, Ishigaki I., 27. v. 1976, T. Ogasawara leg.

Paratypes : Same locality as holotype, 1우, 28. vii. 1976, I. Matoba leg. Mt. Omotodake, Ishigaki I., 1우, 30. viii. 1962, M. Okabe leg. Ushikumori, Iriomote I., 16, 7. v. 1963, K. Morimoto leg. Shirahama, Iriomote I., 1우, 4. iv. 1962, S. Tamai leg.

Distribution : Japan (Ishigaki and Iriomote Isls.).

The penis is characteristic to this new species.

\section{Mechistocerus similis sp. nov.}

(Figs. 8A-F;10DE)

This new species is very close to yaeyamensis and japonicus, but separable from them by the following points. 

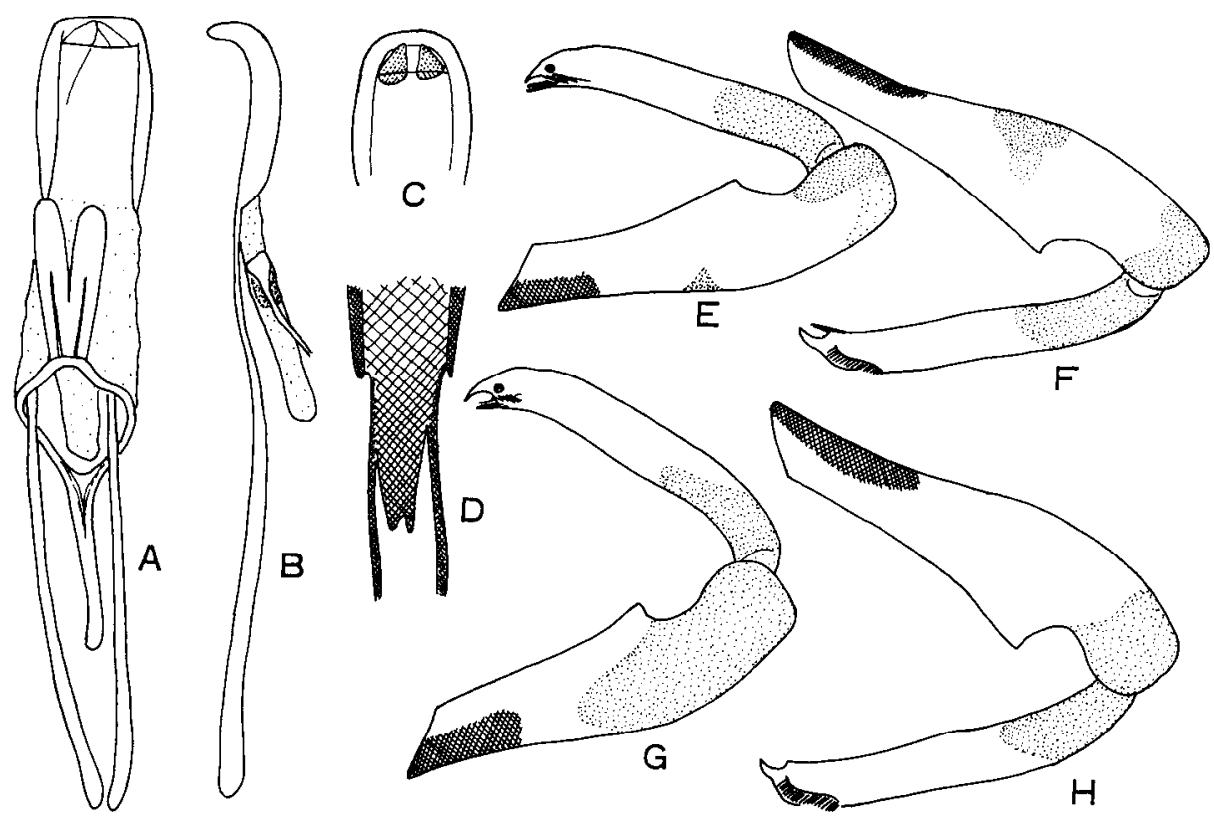

Fig. 8. A-F : Mechistocerus similis sp. nov., $\vec{\sqsupset}$. A : Penis, dorsal. B : Ditto, lateral. C : Apex of penis. D: Basal part of penis, ventral. E: Fore leg. F: Hind leg. G-H : Mechistocerus japonicus Morimoto et Miyakawa, § $\sigma^{7} \mathrm{G}$ : Fore leg. H : Hind leg.

Prothorax weakly convex longitudinally like yaeyamensis, with large reticulate punctures, their interstices much narrower than those in yaeyamensis. Elytra with clear-cut subquadrate or oval punctures in the striae on basal half, punctures much broader than intervals at base and as broad as intervals in the middle, while in yaeyamensis and japonicus striae being much narrower than intervals. Femora each with blackish apex and a median patch like japonicus, but these are not blackish at apex in yaeyamensis.

Aedeagus with penis strongly bent and evenly rounded at apex, ejaculatory duct inserted at the side of internal sac, without sclerite, ventral lobe of internal sac behind gonopore $4 / 5$ the length before gonopore and about as long as main part of penis.

Length : 6.0-9.5 mm.

Holotype male (Type No. 2593, Kyushu Univ.), Mt. Omotodake, Ishigaki I., 18-21. iv. 1975, H. Irie leg.

Paratypes : Same data as holotype, 1우. Same locality as holotype, 1우, 8-11. iv. 1975, H. Irie leg. Mt. Bannadake, Ishigaki, 1ð , 27. x. 1963, Y. Hirashima leg. ;1 , 25. iv. 1974, J. Okuma leg. Otomi, Iriomote I., 1우, iv. 1969, H. Makihara leg. Yona, Okinawa I., 1 우, 29. vi. 1976, H. Makihara leg. Nago, Okinawa I., 1우, 25. viii. 1984, M. Kaneda leg. Mt. Yuwandake, Amami-Oshima I., 1우, 16. vii. 1963, H. Inoue leg. Nishinakama, Amami-Oshima I., 2ㅇ, 3-5. viii. 1969, H. Makihara leg. Mt. Yuidake, Amami-Oshima I., 1우, 3. ix. 1983, K. Hirano leg. Yuwangawa-rindo, Amami-Oshima 
I., 16, 7. v. 1976, J. Okuma leg.

Distribution : Japan (Amami-Oshima, Okinawa, Ishigaki, and Iriomote Isls.).

\section{Mechistocerus japonicus Morimoto et Miyakawa (Figs. 8G-H;10F)}

Mecistocerus japonicus Morimoto et Miyakawa, 1985, Mushi, 50: 51, figs, 18B \& 19. (Hachijo I., Kyushu, Tsushima, Yaku I., Amami-Oshima I.).

Similar to yaeyamensis and similis, but separable from them by the following points.

Pronotum weakly flattened and scarcely conuex longitudinally in the middle, punctures mostly concealed by dense scales excepting the basal area. Elytra with dense scales covering most punctures, which in striae much narrower than intervals. Femora with blackish apical area. Ventral lobe of internal sac in male aedeagus with a characteristic sclerite.

Length : 5.6-10.7 $\mathrm{mm}$.

Specimens examined: 33 specimens including types from Hachijo I., Fukuoka, Oita and Kagoshima Prefs., Tsushima I., Yakushima I., and Amami-Oshima I. I.).

Distribution : Japan (Hachijo I., Kyushu, Tsushima, Yakushima I., Amami-Oshima

The male aedeagus was illustrated in the original description. 


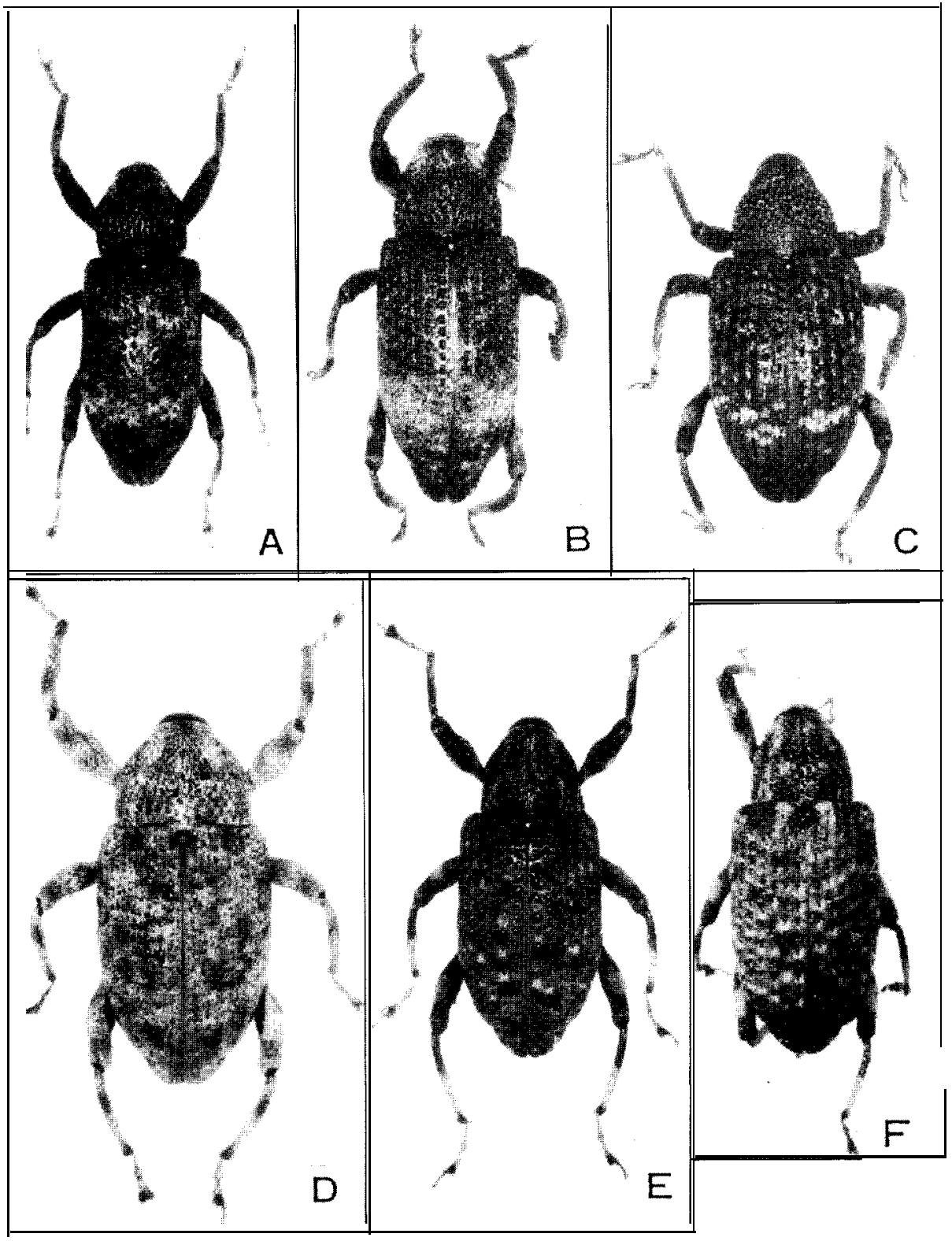

Fig. 9. Mechistocerus spp. A : mgicollis (Roelofs). B : okumai sp. nov. (holotype). C: parcimaculatus Morimoto et Miyakawa. D : ochraceus sp. nov. (paratype). E, F : yakushimanus sp. nov. (E : holotype, F : paratype). 


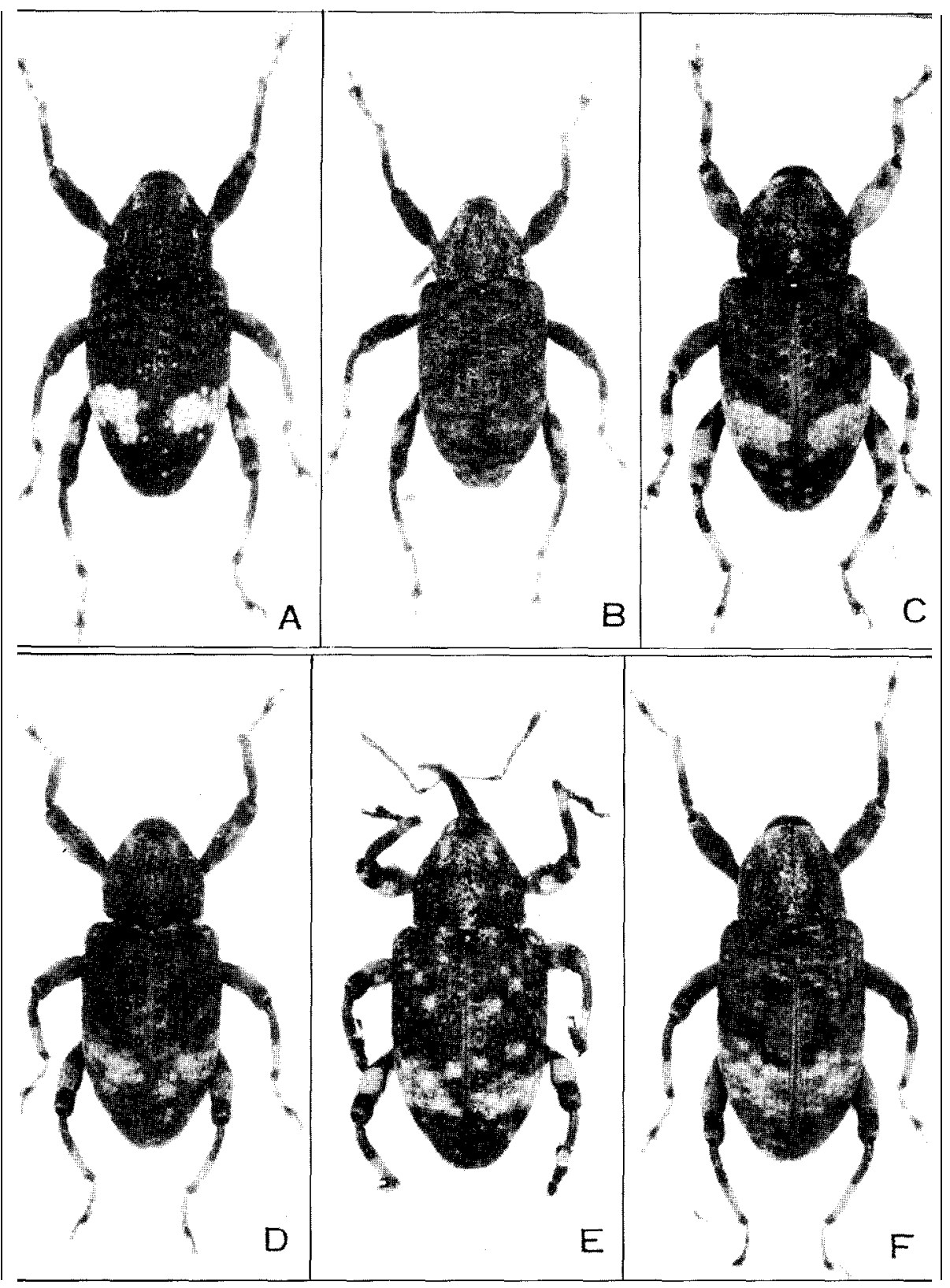

Fig. 10. Mechistocerus spp. A : iriei sp. nov. (holotype). B : nipponicus Kôno. C: yaeyamensis sp. nov. (holotype). D, E: similis sp. nov. (D: holotype, E : paratype). F: japponicus Morimoto et Miyakawa (paratype). 